\title{
Russian language maintenance among multilingual teachers in Israeli educational settings
}

\author{
Galina PUTJATA \\ Goethe University Frankfurt \\ Frankfurt am Main, Germany
}

\begin{abstract}
The present paper focuses on language maintenance among multilingual teachers and presents a research project with Russian-Hebrew speakers on their ideas of language-related normality in educational settings. The main objective is to investigate the role of migration-related multilingual teachers within the 'multilingual turn.' The project approached the topic from three perspectives: the macro level of educational policies, the meso level of educational institutions, and the micro level of linguistic development. Data were collected through biographical interviews with 17 teachers and interpreted within the theoretical framework of language beliefs using the concepts of linguistic market, language awareness and language education policy as well as pedagogical competence. The results show the close interconnectedness of language beliefs on all the three levels. They also show that beliefs can experience a reconstruction. In order to challenge the monolingual idea of normality among teachers, an interwoven intervention on all the three levels is necessary: there is a need for education policy measures (macro level) that would anchor training on dealing with multilingualism (meso level) in regular teacher training and, in doing so, would draw on the existing migration-related multilingual practices of prospective teachers (micro level). This interaction between top-down (professionalization in dealing with multilingualism anchored in educational policy) and bottom-up (migration-related multilingual practices among prospective teachers) measures can enable a shift toward multilingualism as an idea of normality in educational contexts. This paper contributes to a better understanding of the formation, development and reconstruction of language-related idea of normality among teachers and discusses its methodological and theoretical implications.
\end{abstract}

Keywords: multilingual turn, language beliefs, language maintenance, the Russian language, Israel, teacher education, multilingual teacher

\section{For citation:}

Putjata, Galina. 2021. Russian language maintenance among multilingual teachers in Israeli educational settings. Russian Journal of Linguistics 25 (4). 1103-1125. https://doi.org/10.22363/2687-0088-2021-25-4-1103-1125 


\title{
Сохранение русского языка среди многоязычных учителей в израильской образовательной среде
}

\author{
Галина ПУТЯТА
}

\author{
Франкфуртский университет имени Иоганна Вольфганга Гёте \\ Франкфурт-на-Майне, Германия
}

\begin{abstract}
Аннотация
Статья посвящена вопросам сохранения языка среди многоязычных преподавателей и представляет исследование, проведенное с русско-ивритоязычными учителями на предмет их представлений о языковой норме в образовательной среде. Основная цель заключалась в изучении роли учителей в условиях многоязычия. В проекте тема рассматривалась на трех уровнях: макроуровне образовательной политики, мезоуровне образовательных учреждений и микроуровне языкового развития. Данные были собраны посредством биографических интервью с 17 учителями и проанализированы на основании теории языковых убеждений с использованием таких понятий, как языковой рынок, языковое сознание и политика языкового образования, а также педагогическая профессиональная компетентность. Результаты исследования показали тесную взаимосвязь языковых убеждений на всех трех уровнях. Они также показывают, что убеждения могут подвергаться пересмотру. Для того чтобы преодолеть монолингвальную идею нормальности среди учителей, необходимо комплексное взаимодействие на всех трех уровнях: нужны меры на уровне образовательной политики (макроуровень), которые позволят закрепить обучение работе с многоязычием (мезоуровень) в рамках регулярной подготовки учителей, и при этом учитывать существующую многоязычную практику будущих учителей (микроуровень). Такое взаимодействие между мерами «сверху вниз» (профессионализация в области работы с многоязычием, закрепленная в образовательной политике) и «снизу вверх» (многоязычная практика будущих учителей, связанная с миграцией) может обеспечить смещение в сторону многоязычия как идеи нормы в образовательных контекстах. Результаты данного исследования способствуют лучшему пониманию формирования, развития и пересмотра идей языковых норм среди учителей и включает в себя обсуждение методологических и теоретических выводов, полученных в результате исследования.
\end{abstract}

Ключевые слова: многоязычный подход в образовании, языковые убеждения, сохранение языка, русский язык, Израиль, педагогическое образование, многоязычные учителя

\section{Для цитирования:}

Putjata G. Russian language maintenance among multilingual teachers in Israeli educational settings. Russian Journal of Linguistics. 2021. Vol. 25. № 4. P. 1103-1125. https://doi.org/10.22363/2687-0088-2021-25-4-1103-1125

\section{Introduction: Multilingual societies and monolingual education systems}

Multilingualism is a social reality. The exact number of children and adolescents who grow up multilingual is unknown and is not recorded statistically. Indirect indications can be found in statistics on the so-called migration background with numbers, for example in Germany, reaching up to 60\% (BpB 2019: 40). These figures do not reflect the language constellations (languages of parents, siblings, common family languages) nor the actual linguistic practices of individuals. For pedagogical practice, these figures have a significant consequence: teachers and pupils bring various language varieties, sociolects, regiolects and different 
linguistic registers as a basis for learning processes. This linguistic heterogeneity continues in the face of transnational mobility. Socioeconomically or politically motivated ("refugee migration") or supported by internationalization funds such as Erasmus, this voluntary and involuntary mobility continues to shape societal multilingualism. In international discourse, this societal development has led researchers from different fields to further develop and broaden the focus to dimensions going beyond linguistic systems, using the terms 'plurilingualism' and 'superdiversity' (Creese \& Blackledge 2018, García \& Otheguy 2020).

At the same time, most education systems are nation-state oriented and, consequently, national language oriented (Brizić \& Hufnagl 2016, Krüger-Potratz 2013, Cummins 2010). This monolingual orientation is at odds with the linguistic heterogeneity presented. On the one hand, this discrepancy leads to the disadvantage of all those who deviate from the dominant societal norm and affects the educational success of children who grow up multilingual. This also has consequences for their linguistic development: multilingualism, how it emerges and how it develops, depends significantly on how society deals with languages (Irvine $\& \mathrm{Gal} 2000$, Schmid 2010). The monolingual orientation of educational institutions shapes individual linguistic development and can lead to language rejection in multilingual children and adults (Lanza 2007). On the other hand, monolingual orientations also affect teachers: when they expect to teach a homogeneous monolingual learners' group, multilingualism comes to be seen as a deviation from the norm and, thus, a challenge in everyday teaching practice (Becker-Mrotzek et al. 2012, Huxel 2018, Mary \& Young 2018).

Worldwide, researchers from various disciplines have been calling for a shift towards multilingualism as an idea that belongs to normality. In the field of multilingualism and education, this call is justified with psycholinguistic and sociopolitical arguments about cognitive and linguistic transfer, the importance of all linguistic resources in learning processes, the valorisation of the deficit perspective on linguistic minorities, the use of migration-related resources, and equal participation as a principle of democratic society (Conteh \& Meier 2014, García \& Wei 2014, Meier 2017, May 2019).

Over the past decade, data from empirical classroom and school research support the psycholinguistic and socio-political arguments described above. Studies show that the implementation of migration-related multilingualism proves positive for the learning of all the pupils. This is evidenced by findings on multilingual literacy activities (Gawlitzek 2013, Melo-Pfeifer \& Helmchen 2018, Oomen-Welke 2013), studies on methods of teaching multilingualism in foreign language classrooms (Bonnet \& Siemund 2018, Fernández Amman et al. 2015, Hu 2018, Candelier et al. 2012), and also on the productive use of family languages in mathematics and science classrooms (Gantefort \& Sánchez Oroquieta 2015, Gürsoy \& Roll 2018, Prediger \& Özdil 2011). Finally, studies on classroom interaction complement these findings (Duarte 2016).

These psycholinguistic and socio-political arguments, complemented by the findings of empirical classroom and school development research, form the basis 
for the "multilingual turn" (Meier 2017) that has meanwhile been requested internationally - a shift towards linguistic heterogeneity as a feature of normality in educational contexts. Yet, despite the above theoretical discourses, scientific arguments, proven effective methods at the classroom level and school development concepts at the structural level, teachers in many countries continue to align to a monolingual norm (Huxel 2018 for Germany, Gkaintartzi et al. 2015 for Greece, Mary \& Young 2018 for France, Pulinx \& van Avermaet 2015 for Belgium).

The question remains: how can these monolingual ideas of normality be challenged? A key role in this process has been attributed, in political discourse, to immigrant teachers as experts in dealing with linguistic and cultural diversity. This perspective has led policy actors around the world to call for a more diverse teaching body (CNN Wire Staff 2010, Ingersoll \& May 2016, BReg 2015). To date, however, there is little empirical evidence showing support for these expectations (for a current overview see Goltsev et al. 2021).

The paper addresses this research goal by examining the perspectives of migration-related multilingual teachers on language-related notions of normality in educational contexts. The data draw on the research project "Language biographies of migration-related multilingual teachers"1, which approaches this central question from different perspectives: the macro-level of educational policy, the meso-level of educational institutions, and the micro-level of multilingual development and self-positioning. I will first introduce this multi-perspective approach in the theoretical framework on language beliefs (Section 2) and give a brief literature overview on educational policies as well as migration-related multilingual teachers. The research project itself draws on field research in Israel. The reasons for this choice, as well as the methodology of biographical interviews with Russian-Hebrew speakers, are explained in the context section followed by the presentation of five sub-studies with underlying research questions in (Section 3). Finally, I will present the central findings of the studies (Section 4) before discussing their implications for multilingualism research (Section 5).

\section{Theoretical framework: Language beliefs in education}

The theoretical basis for the study of language beliefs in educational contexts derives from a consideration of ideas about language from educational, psycholinguistic and sociolinguistic perspectives.

\subsection{Language beliefs and their emergence on micro-, meso- and macrolevel}

Language beliefs were first considered for the present project from the pedagogical perspective. Already in the 1990s, Pajares described beliefs as a part

${ }^{1}$ The project was conducted between 2014 and 2019 by the author. The field research in Israel took place between July and September 2015 with the support of the Ernst Ludwig Ehrlich Studienwerk, and data analysis was funded by Department 06 of the Westfälische Wilhelms-University of Münster. 
of pedagogical competence and as a "messy construct" (Pajares 1992: 327), and until today this concept remains vaguely defined. According to Baumert and Kunter (2006), in the competence-oriented view on teachers' professionalism, beliefs form one of the three core components of pedagogical competence: knowledge, action strategies, and beliefs. Knowledge is described as a cognitive component - the professional, pedagogical, and methodological knowledge that teachers possess. Action strategies describe the pedagogical ability - the action practices directed to pupils. These two components are primarily objective. Beliefs, on the other hand, are subjective and differ substantially from content, pedagogical or methodological knowledge. They are based on normative conceptions rather than on. These ideas are affectively loaded and contain a judgmental component. At the same time, they are considered to be true and provide structure to profession-related action (Reusser et al. 2011).

Since language beliefs shape pedagogical action, it is all the more important to consider their emergence and development. For this purpose, in addition to the competence-oriented professional perspective, I also included findings from sociolinguistics in the project. In these disciplines, the concept describes ideas "about the world, and the relationships between objects of social significance: e.g., judgements of standard language varieties tending to be associated with high-status jobs" (Garrett 2010: 23).

These ideas about languages and their role in the lives of multilinguals are reflected at the micro-level of individual speakers. In psycholinguistic research, language beliefs are used to describe the emergence of language attitudes. Since the 1960s, language attitudes have been considered as an individual affectivemotivational factor in language production and perception (cf. Garrett 2010). Studies on motivation in second language acquisition and acculturation ((Schumann 1978) drew on these findings and developed concepts, such as the language ego (Guiora et al. 1972) or the affective filter (Krashen 1987), to explain individual differences in acquisition processes through attitude differences. Moreover, for some years now, neuroscientific work has been investigating how emotions affect language acquisition processes, pointing to qualitative differences in language processing and storage (Pavlenko 2007b, see for an overview Putjata 2014, 132-143). Sociological studies also frequently make use of immigrants' language attitudes to describe linguistic integration processes (Prashizky \& Remennick 2015).

In psycholinguistic research, language attitudes are understood as an internal characteristic of a person that develops before migration and determines (language) integration behaviour. Representatives of sociolinguistics reject this position as untenable in view of the complexity of multilingual societies and the processes of transnational mobility. Language beliefs, according to this discourse, are only constructed and produced in interaction. In contrast to the psychological view, they are not understood as a source of linguistic practices, but as their product; consequently, they are not an internal psychological (and thus individual), but a 
social phenomenon (Bucholtz \& Hall 2005, Pavlenko \& Blackledge 2004). Thus, it is not primarily individual language attitudes that are causal of certain behaviour patterns. On the contrary, linguistic attitudes emerge only in interaction and as a product of social evaluation. In sociolinguistic language ideology research, a distinction is made between the concept of discursive language ideologies and cognitive language attitudes (Spitzmüller \& Warnke 2011).

According to findings on language policy, these discursive language ideologies are in turn the product of socio-economic conditions and are shaped by the macrolevel of language policy. Language and education policies determine and regulate language use in public institutions of education (Spolsky 2017) and can affect the micro level of individual linguistic practices (Lanza 2007). At the meso level, they determine the language ideologies that prevail in educational contexts. At the same time, however, public discourse shapes language policies, so that language policy functions as an agent of public discourse. Hence, languages function as symbols of social organization and are constitutive of power hierarchies. In this process, social meaning is assigned to linguistic varieties in certain contexts by declaring some linguistic forms as norm, while others are classified as inferior (Blommaert 2010, Roth et al. 2018, Putjata 2018b for an overview).

The institution of school plays a particular role in this process. Here, according to Bourdieu (1990), individuals experience the value of their linguistic products: knowledge of a legitimate linguistic form is rewarded, while the use of other forms (minority languages or substandard varieties) is sanctioned. Grades and certificates showing knowledge of legitimate languages function as capital and are considered a decisive criterion for access to school or university studies (Fürstenau \& Gomolla 2011). Due to its social and epistemic function for educational processes, language determines scholastic and professional success. Yet, which languages are assigned which capital value is defined by the groups with the largest capital volume, so that language beliefs are circulated and reproduced in schools (Fürstenau \& Gomolla 2011).

In the pedagogical perspective presented at the beginning, language beliefs shape linguistic notions of normality. Against the background of their significance for pedagogical action, and ultimately for the educational biography of migrationrelated multilingual children, the question arises as to how this reproduction of power relations can be challenged. This question will be explored in the following sections.

\subsection{Challenging language beliefs: The role of educational policies}

The possibilities of challenging the reproduction of power relations are discussed in research across disciplines (Menken \& Garcia 2010), as language beliefs prevalent in schools are shaped by societal language ideologies. These, in turn, are the product of language policy at the macro level (Spolsky 2017). Consequently, language policies are necessary in order to initiate transformational processes concerning the linguistic profiles of the school (Shohamy 2010). 
Numerous overt and covert top-down and bottom-up mechanisms are at work here and can constrain or facilitate implementation. Teachers play an important role as actors at the interface between top-down policies and de facto language practices (Shohamy 2010). In the model of school as linguistic market (Bourdieu 1990), teachers also function as ideology brokers who circulate language ideologies (see Blommaert 2010, Putjata 2017a, Yelenevskaya \& Protassova 2021 for an overview).

Shohamy (2010) criticizes the fact that laws are often initiated by groups with power, bypassing those who ultimately have to implement them in practice, and argues for the active involvement of teachers in this process. This would, in turn, require teachers to see themselves as active actors of educational processes. In research on Language Awareness, the need for a "sensitivity to and conscious awareness of the nature of language and its role in human life based on knowledge, values and a deeper understanding of the complexities of living and learning in multiple languages" (Donmall 1985) is well established (Association for Language Awareness 2021).

\subsection{Challenging language beliefs II: The role of migration-related multilingual teachers}

The language awareness discussed in the last section is presumed to be paramount among migration-related multilingual teachers. In terms of multilingualism, multilingual teachers are expected to have a number of potential advantages for the multilingual practices in everyday teaching outlined in Section 1. At the instructional level, their inclusion in team teaching and coordinated literacy instruction is a fundamental prerequisite for numerous approaches. The studies already outlined, for example in mathematics, foreign language, and literacy didactics, confirm the positive impact of multilingual practices on learning processes. Multilingual teachers would consequently be potentially able to build on children's existing linguistic resources, and thus support linguistic and cognitive transfer as well as subject learning and language education in literacy activities (see arguments in Section 1). Within the outlined theoretical framework of language beliefs, migration-related multilingual teachers have a particular role on the schools' language profiles. As ideology brokers who circulate language ideologies (see Section 2.1), they themselves represent a powerful social group. In their feedback on minority languages, they could become agents for change, challenging dominant linguistic practices and circulating multilingual language ideologies (Bräu et al. 2013, Lengyel \& Rosen 2015, Georgi et al. 2011). Finally, at the intersection of top-down and bottom-up processes in terms of language education policy (Hino 2021), they can drive educational policies to empower migration-related multilingualism by contributing as de facto policy makers to the legitimization of minority languages in everyday communication (see Section 2.1). 


\section{Studies with Russian-Hebrew speaking multilingual teachers}

So far, there is little or no empirical evidence to support these assumptions discussed above. Only a few studies focus on multilingualism and find monolingual orientations in multilingual teachers' practices (Panagiotopoulou \& Rosen 2016). However, the underlying beliefs behind these practices remain unclear. Consequently, the project described here aimed to reconstruct the development of multilingual teachers' language beliefs over the course of their educational and professional careers. To do so, I conducted five sub-studies that analysed linguistic development and self-positioning as well as the construction of identity in different (mono- and multilingual) educational contexts. In what follows, I will present these studies focusing on their contextual framework, data collection and evaluation.

\subsection{Contextual framework and research questions}

The studies presented here draw on the research project "Language biographies of multilingual teachers in Israel". This context was chosen because of Israel's long history of migration and its particular educational policies.

Like many other countries, Israel sees itself as an immigration society. However, while in many countries this self-image did not develop until the beginning of the new century, the entire history of Israel is based on immigration. As with many of these countries, Israel's language policy was shaped by homogenization efforts (Spolsky \& Shohamy 1999). As part of a nation-building process, the Hebrew language became an important instrument of identity formation. To this end, the language of the Holy Scriptures, which until then had only been intended for religious contexts, was declared the language of the state, and its legitimacy was secured in formal and informal situations. "Ivri, daber ivrit!" [Hebrews, speak Hebrew!] - in the spirit of this language ideology, Hebrew language became the criterion of loyalty to the State of Israel and the only language of communication for everyone shortly after immigration (Ben Rafael 1994). This language regime of Israel shaped argumentation regarding the integration of new immigrants: national unity is based on monolingualism, and learning Hebrew is the conditio sine qua non for integration. The result of preserving other languages was to weaken national identity (Shohamy 2008).

This socio-political discourse underwent a radical change in the 1990s, when immigration from the (post)Soviet Union and North Africa increased Israel's population by $20 \%$. As a result, for the first time Israel positioned itself in political discourse as a migration society with an urgent need for change in the education system (Spolsky \& Shohamy 1999). In response to the rapid increase in the number of pupils and the growing linguistic diversity, "new immigrant teachers" were to be integrated into the regular school system. The resulting education policy measure "New Immigrant Teacher Absorption" became part of the socio-political discourse and was promoted by the Ministry of Education and the Ministry of Professional Absorption. The law was implemented through a series of explicit measures: the ministries secured funding, and a new degree program was implemented. New 
immigrant teachers and academics interested in pedagogical work were to complete a one-year qualification course in the Israeli school system, with 20 hours on school subjects and their associated didactic practices (with teachers' home languages as a possible subject). An intensive 20h-course in Hebrew language complemented the course. At the end, the teachers completed a one-year mentoring program sponsored by the Ministry of Education (Levenberg et al. 2013, Berger 2001, Horowitz 2003, Remennick 2002).

A few years later, the Ministry emphasized the importance of preserving the linguistic resources of the arriving population. In doing so, it publicly positioned the earlier policy of linguistic assimilation as an "unfortunate loss of the potential of early immigrant languages" and promised "efforts to correct this" (Spolsky \& Shohamy 1999). In 1995, with the declaration of the "New Language Education Policy," new immigrant pupils were encouraged to learn Hebrew and to preserve the languages they spoke at home at the same time. The implementation led to more explicit measures, including the introduction of Russian and French as a second foreign language (after English) and Ladino, Amharic, Yiddish, Spanish or German as an option from the fifth grade. New immigrant pupils were also to receive additional support in family languages to ensure the further development of academic competencies (Muchnik et al. 2016). This, in turn, increased the need for teachers who would be able to teach these advanced language courses and created the conditions for the professional integration of adult migrants as teachers (see further Putjata 2018c).

Given the theoretical framework of school as a linguistic market presented in Section 2, the importance of educational policies and migration-related multilingual teachers, these changes provided an appropriate research context and offered the basis for the five sub-studies with Russian-Hebrew speakers. The following questions guided the research:

Study 1: To what extent have speakers of Russian perceived differences in educational contexts? How has their self-perception as migrant-related multilinguals developed in these different educational contexts? (Putjata 2017b).

Study 2: (How) did such a macro sociological shift shape linguistic development and the formation of linguistic identity construction among young multilinguals? (Putjata 2018b).

Study 3: How did newly immigrant teachers perceive their own role in the Israeli education system? To what extent did they notice differences in language status and how did their own perceptions of migration-related multilingualism develop in these contexts? (Putjata 2018c).

Study 4: To what extent did pupils perceive (newly) immigrant teachers? What role did they play in pupils' perceptions of themselves as migration-related multilinguals in the new imagined community? (Putjata 2017a).

Study 5: How do migration-related multilingual teachers perceive the multilingualism of their pupils today and how has this perception developed in the course of their own life and professional biography? How do they describe dealing with multilingualism in their own teaching practice? (Putjata 2018a). 


\subsection{Data Collection}

During the fieldwork in summer 2015, I collected a total of 17 language biographies and 11 expert interviews. The expert interviews served to capture the educational policies and implementation measures, while language biographies allowed access to individual perspectives of migration-related multilinguals who had experienced the Israeli educational context as pupils or teachers during the socio-political changes.

\subsubsection{Interviews with experts}

In order to capture the organizational measures for policy implementation, I interviewed people who are considered experts in this field. This group included scholars who had researched and scientifically accompanied the measures or who had themselves been involved in the implementation. These interviews gave me the first access to the field. I contacted the experts in advance per e-mails, based on my literature research in the field of language, education and migration: for example, Gabriel Horenczyk on the professional integration of teachers, Marina Niznik on language policy, Larissa Remennick on capital in migration and Mila Schwartz on multilingualism in educational contexts. Subsequently, I was able to reach further experts via the snowball principle, so that I conducted a total of 11 interviews. These interviews provided an important basis for accessing educational policy documents as well as learning about actual implementation. For example, Marina Niznik and colleagues undertook a very detailed analysis of educational policies implementing the languages of (recent) immigrants (Muchnik et al. 2016) and Larissa Remennick compared the professional integration of Russian-speaking teachers in different countries (Remennick 2002). What was missing from this body of research, according to these interviews, was the perspective of the individuals themselves who experienced the Israeli education system in these processes of change. For this reason, I based my publications on their existing work and focused on collecting language biographical interviews in the rest of the field research.

\subsubsection{Language biographical interviews}

Data were collected through narrative interviews focusing on language biographies (Franceschini 2002): respondents were asked to reflect openly on what languages they spoke, with whom, and when, and how this had changed over the course of their lives. This instrument was chosen because language biographies provide access to individual speakers' perspectives on their language lives: by reconstructing their own language biographies, individuals not only reveal their subjective theories about language acquisition or use, but also reflect on their perceived role in the society (ibid), with certain languages proving useful or hindering them. In doing so, they orient themselves to the prevailing language hierarchy, whereby certain positions are assigned to certain groups of speakers. Thus, they are always positioning themselves and others (Auer \& Dirim 2003, 
König 2018). It was precisely this allocation, the construction of certain roles for speakers of different languages in a society and the expression of language status as negotiated on the linguistic market, that was the focus of my studies.

I conducted the interviews personally. As a Russian speaker who had immigrated to Germany in the 1990s under similar circumstances, I shared the migration experience from the dissolved Soviet Union. I refer to the economic and social changes in the former CIS states as similar circumstances. This experience laid the necessary common ground for the interviews. This basis was further extended by the common languages: Russian as the official state language of the Soviet Union was completed in many interview conversations by English and Hebrew. For biographical research, this shared migration history represented a potential advantage, as it produced a particular sense of closeness due to the common language and socialization experiences (Agha 2007). In addition, when I first made contact, I introduced myself as a teacher and now a lecturer in the field of teacher education. This also provided common ground in terms of professional experience. With this shared horizon of experience, I attempted to overcome the power asymmetry in the research context. At the same time, the different contexts - Germany and Israel allowed me to assure the necessary distance from the research field and to conduct interviews with authentic questions on the education system in Israel.

\subsubsection{Participants}

To recruit participants, I reached out to individuals in rural and urban areas of Israel through social media and academic networks. The most important criterion was the profession of the participants: they all had to be migration-related multilinguals and currently working as teachers in the Israeli education system. This allowed me to interview individuals who had completed their entire educational biography, from kindergarten to professional training in Israel, as well as multilinguals who encountered the Israeli educational context at an advanced age, with an international teaching diploma. The resulting data corpus included interviews with 17 individuals who emigrated from the Soviet Union between 1990 and 2000. This group was selected because it constituted the largest minority in Israel at the time of the data collection, with 17.6\% (see Central Bureau of Statistics 2015). External factors shared by these immigrants were the collapse of the Soviet Union and changes in Israel's linguistic educational landscape in the 1990s. At the time of immigration, participants were between 2 and 41 years old. Thirteen of them were children and adolescents themselves at the time of the educational changes and reported on their experiences as pupils. Four of them had already graduated and encountered the education system as teachers. At the time of the interview, they had been working in the education system for between 1 and 20 years.

\subsection{Data analysis}

The audio-recorded data were transcribed and analysed by three independent researchers following a theory-guided coding. The basic approach was guided by qualitative content analysis according to Mayring (2010) as well as the 
reconstruction of the discursive construction of experiences (Pavlenko 2007a). New theories emerged in the course of data analysis, arrived at deductively from considering the corpus. These theories were verified and reapplied to the material. This approach led to the elaboration of the theoretical framework on language beliefs presented in Section 2.

Thus, I first examined the "New Language Education Policy" in schools from the perspective of the multilinguals themselves, guided by theory and oriented towards Bourdieu's economy of linguistic exchange (1990). At the same time, the first perusal of the data showed that the educational policy changes had a significant role for personality development in terms of constructed linguistic identity. For this reason, in the second study I examined how the macro sociological processes of change in Israel shaped the linguistic identity construction among multilinguals. The theoretical basis for this was provided by Anderson's (1991) concept of imagined community. This second study showed, among other things, that multilingual teachers played a prominent role in the personality development of their pupils. Subsequently, in the third study, I re-examined all data with regard to the role of multilingual teachers in the process of identity construction. The coding of the data was guided by Anderson's concept of imagined community and the state of research on immigrant teachers. For the teachers to function as role models, however, the teachers themselves must have developed a perception of multilingualism as normality, as the findings confirm. This, in turn, was shown by initial analyses from the data with multilinguals who had already migrated to Israel in possession of a teaching diploma. For this reason, further data were used with teachers who had arrived in Israel in their adult years. These data were re-examined in the fourth sub-study, against the background of research on downward social mobility in migration contexts, drawing on the theory of "capital in migration" (Remennick 2002). Finally, in the fifth and last study, I used typology-building methods to analyze language-related notions of normality among migration-related multilingual teachers in Israel.

\section{Selected findings and open questions}

As outlined in the last section, five sub-studies emerged from the research project, investigating the following aspects: the emergence of pupils' language beliefs in different educational contexts (Study 1); processes of linguistic identity construction among multilinguals as a consequence of macro-sociological change (Study 2); the access of newly immigrated teachers to schools as a working field (Study 3); the significance of their presence in the education system (Study 4); and the described handling of multilingualism in their own pedagogical practice (Study 5). This design was chosen because of the close interconnectedness of language beliefs at the different levels. In order to understand the source of migrant multilingual teachers' pedagogical practices, the underlying language beliefs and how they are shaped must be reconstructed from a sociolinguistic and sociological perspective. The following section will provide selected findings on individual 
biographical experiences as well as on language beliefs, their emergence and development in different settings.

- A person's migration background does not provide any information about his or her actual multilingual practices. Even existing individual multilingualism does not provide an indication of the perception of multilingualism as capital in Bourdieu's sense of the economy of linguistic exchange (see Bourdieu 1998 in Section 2). A major role in the formation of this perception is played by the way in which multilingualism is dealt with in the education system. This is shown by the study on the 'New Language Education Policy' with multilinguals in Israel who experienced different educational contexts. Participants who experienced a monolingual setting reproduce it in their current lives. Participants who have experienced their family language as institutionalized perceive multilingualism as an asset today. However, this perception is not static and closed. The third group shows that this perception can also change. However, this change requires educational policy measures that implement migration-related multilingualism in the curriculum of the education system and declare it an institutionalized cultural capital (Study 1, Putjata 2017b).

- A special role in this process is played by the indexical function, the meaning assigned by this educational policy measure to the respective languages in the sense of Blommaert (2005, see Section 2). This is shown by the study that reconstructs language attitudes in the process of identity construction. Interviewees who experienced a monolingual environment after migration recall the desire to fit in as the reason for their new "more Hebrew" names, and the decision to speak Hebrew exclusively with the family. The state language is assigned an integrative function as significant for participation in education and society. Consequently, integration in society means discarding everything that is hindering, including their family language, Russian. Multilinguals who were socialized after the shift in sociopolitical discourse report positive feedback regarding their knowledge of the family language. Implemented in the curricula, language was assigned more than just an identitary function, which is reflected in the participants' self-perception: they now understand multilingualism as an important resource in life and are eager to pass the Russian language on to their children. These participants did not experience speaking Russian as a contradiction to equal participation, and see themselves as legitimate members of a multilingual community (Study 2, Putjata 2018b).

- A significant part of the formation of this imagined community (Anderson 1991) as a multilingual society was contributed to by immigrant teachers who multilingual Israelis themselves had in their school years. Without being asked about it, immigrant teachers were mentioned in many of these interviews. The study reconstructing their role shows that they were important for pupils' self-positioning as immigrant multilinguals in the new society: as part of the imagined community and for the legitimacy of Russian language in informal situations (see ideology brokering in Section 2). "My teacher had an accent too." As children and 
adolescents, they did not experience accented pronunciation among authority figures as a hindrance and consequently perceived themselves as legitimate members of a linguistically heterogeneous society (Study 3, Putjata 2017a).

- However, this presupposed that the teachers themselves function as multilingual brokers (Blommaert 2005), that is, that they themselves perceive multilingualism - and the use of the Russian language in particular - as legitimate. However, this perception can only develop if newly immigrated teachers experience access to the working field of school as a type of inclusion through interdependence, and if the linguistic resources they bring with them are understood as capital. This is shown by the study that investigates the access and self-positioning of newly immigrated teachers within the linguistic market of the school. Newly immigrated teachers are able to transform the school's linguistic market by circulating multilingual ideology. Educational policies such as "New Immigrant Teacher Absorption" are a basic prerequisite for this transformation. Political intervention for the professional integration of immigrant teachers represents an official statement in the discourse of educational policy. Implemented through diploma recognition, teacher training, and mentoring programs, it contributes to a change in the discourse around immigrants and their social status, historically afforded minority status in the eyes of society. At the same time, professional integration has positioned teachers not as immigrants in need of help, but as experts at eye level. As self-confident multilinguals, they become de facto policy makers in the language market of the school, in the sense of Shohamy's (2010, see Section 2) theory on language policy making (Study 4, Putjata 2018c).

- All of the participants in the four presented sub-studies are themselves working as teachers in Israel today. Their own (described) dealings with linguistically heterogeneous groups and their perception of multilingualism were the focus of the fifth study on the emergence and development of language beliefs in the course of educational and professional biographies. This study shows that even if teachers are multilingual, even if they perceive and use multilingualism as a resource for themselves and society, this is not reflected in their described pedagogical actions. These results underline the importance of explicit professionalization in dealing with multilingualism in classroom (Study 5, Putjata 2018a).

This presentation of the main findings is highly simplified and invites a number of challenges, which I address in more detail in publications on the research. For example, the first study with pupils revealed that not all interviewees who attended school after 1995 experienced the changes in the school system. They do not recall languages other than Hebrew playing a role in interactions with teachers or in the curriculum, which raises questions about the role of different actors in policy implementation. Other studies confirm that the language education reform in Israel was implemented rather inconsistently and that the process took longer in some schools (Shohamy 2010). Another challenge that emerged in the interviews 
concerned the language classes and materials offered in the family languages. Participants who had moved to Israel as children found the institutionalized Russian language classes too difficult. The academic language register seems to be too challenging for students who only experienced the language in everyday life without ever having learned to read and write it. This finding raises further research issues directed at specific intervention: the development and study of new tools, textbooks, curricula, and teacher training adapted to the new needs of multilinguals in migration contexts.

Furthermore, the findings question the extent to which the perceived positive response to family languages can be interpreted as a general valorisation of migration-related multilingualism. Rather, the data in Israel suggest that Russian experienced a revaluation, while this is not the case for Amharic - the language of Ethiopian immigrants. Other studies on language policy in Israel confirm that Amharic as a family language has not been implemented in the regular school system (Shohamy 2010, Muchnik et al. 2016). Ethiopian pupils are described as generally less talented, which is more indicative of a restructuring of the linguistic market: Russian has gained a higher status, while other languages have lost in status.

This observation is confirmed by findings with teachers who were reprofessionalized in Israel: as presented in the narratives about the "New Immigrant Teacher Absorption" course, respondents only remembered fellow teachers from the Soviet Union, France, and the United States, although migration in the 1990s also included many people from North Africa. Based on these data, it is possible to assume that the latter minority group did not participate in the program. This suggests that there was no increased acceptance of multilingual teachers by the education system in general, but rather a restructuring of the linguistic market: this would suggest that while the language hierarchy changed (with the upgrading of Russian), the problem as such remained - the production and reproduction of social power relations in schools.

\section{Discussion and Conclusion: Multilingualism as an idea of normality in educational settings}

The five presented studies show the close interconnectedness of language beliefs on the three levels - the micro level of language development and positioning practices, the meso level of educational contexts, and the macro level of educational policy. However, they also show that language beliefs related to linguistic homogeneity at school can experience a reconstruction. In response to the overarching research question, "How can the monolingual idea of normality be challenged among teachers?", the research project shows that there is a need for interwoven intervention on all three levels: education policy measures (macro level) are needed that would anchor training on dealing with multilingualism (meso level) in regular teacher training and, in doing so, would draw on the existing 
migration-related multilingual practices of prospective teachers (micro level). This interaction between top-down (professionalization in dealing with multilingualism anchored in educational policy) and bottom-up (migration-related multilingual practices among prospective teachers) measures can enable a shift toward multilingualism as an idea of normality in educational contexts. In the following section, I will summarize these findings and their significance for multilingual practice and research.

Multilingual teachers can be an example for multilingualism in educational contexts and an important resource for change in the linguistic market of the school. The studies show the interconnectedness of the three levels. The perception of multilingualism as capital on the micro level depends to a large extent on one's own biographical experience with migration-related multilingualism. The migration background, as such, does not result per se in multilingualism and even existing multilingualism does not automatically lead to its perception as a resource. As reconstructed in the language biographies, this development is the result of political dealings with multilingualism on the macro level, as reflected on the linguistic market of educational institutions on the meso level. Past experience with multilingualism plays a significant role in this process. When multilingualism is experienced as a prerequisite and medium for learning processes and educational success, teachers reproduce this perception in their own pedagogical practice with linguistically heterogeneous pupil groups.

For already trained teachers who migrate as adults, the development of language beliefs depends on their access to the labour and education market and on the role that is politically assigned to the languages they speak. The possibility of professional integration with recognition of existing pedagogical and linguistic resources leads teachers to perceive their migration-related multilingualism as an asset. The situation is similar for teachers who grew up multilingual as children or adolescents. The way society approaches multilingualism shapes their current language beliefs. Teachers who have experienced the use of Russian as legitimate in everyday interaction and as capital for learning and educational success understand migration-related multilingualism as a significant resource for their pupils and for society as a whole. In a context where only the state language is accepted, teachers develop beliefs that reproduce the social status of multilingualism as a deviation from the norm, and see the multilingualism of their pupils as insignificant or even as a hindrance.

However, these beliefs are not monolithic constructs that, once formed, remain stable. They are fluid and open to change. These findings highlight the need to develop further didactic methods that include biographical analysis and take them up as a reflexive moment for all participants in teacher education. This should take place not in additional programs, but in regular teacher training. The constructive implementation of migration-related multilingualism in teacher professionalization leads to their integration as equals and the reconstruction of self-perception in 
migration-related multilingual teachers. In terms of socio-political discourse, it enables equal participation that recognizes existing resources and makes them socially relevant. Applied to teachers and professionals, these findings show that dealing professionally with multilingualism in a migration society is the task of all teachers. However, the existing teachers' migration-related resources should be addressed in the process of developing this professionalism. The ability to deal with linguistic diversity should not only be a desirable outcome, but rather should be included as an important prerequisite for all future teachers.

Finally, on the methodological level, the multi-perspective analysis shows the need to approach multilingualism and education in a migration society in an intertwined way. Psychological foundations for cognitive and linguistic learning processes need to be further investigated with a focus on multilingual practices (e.g., translanguaging or code-switching) in the classroom; this level needs to be complemented by further socio-political research on hegemonic dynamics of language(s); furthermore, corresponding concepts and methods of multilingual classroom and school development, as well as their transfer into mainstream education, would need to be further investigated. Here, interdisciplinary and multimethod approaches are also necessary in order to capture linguistic practices in educational contexts.

The present paper contributes to the research on the language maintenance of post-Soviet immigrants. Yet, in the light of ever-increasing transnational and global mobility, the significance of the multilingual turn in teacher education and practice extends far beyond individual language development. Both multilingualism and teacher education, as well as their interaction are critical aspects in issues of equal opportunities, educational equality and social cohesion. Thus, from a wider perspective, this topic will always be framed by questions of language-responsible teaching and equality in education.

(C) Galina Putjata, 2021 ccreative

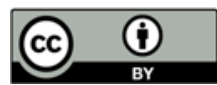

This work is licensed under a Creative Commons Attribution 4.0 International License https://creativecommons.org/licenses/by/4.0/

\section{Acknowledgements}

I thank Ksenija Gumenik and Liana Kotliar for assistance with data evaluation. I am also grateful to Helena Olfert and two anonymous reviewers for comments on an earlier version of the paper. Any remaining errors and inconsistencies are mine alone.

\section{Disclosure statement}

There is no potential conflict of interest to report. 


\section{REFERENCES}

Agha, Asif. 2007. Language and Social Relations. Cambridge: Cambridge University Press.

Association for Language Awareness. ALA Definition. http://www.lexically.net/ala/ la_defined.htm (accessed 26 July 2021).

Auer, Peter \& İnci Dirim. 2003. Socio-cultural orientation, urban youth styles and the spontaneous acquisition of Turkish by non-Turkish adolescents in Germany. Constructions of Youth Identities. In Jannis. K. Androutsopoulos \& Alexandra Georgakopoulou (eds.), Discourse Constructions of Youth Identities, 223-246. Amsterdam: Benjamins.

Baumert, Jürgen \& Mareike Kunter. 2006. Stichwort: Professionelle Kompetenz von Lehrkräften. Zeitschrift für Erziehungswissenschaft 9 (4). 469-520.

Becker-Mrotzek, Michael, Britta Hentschel, Kathrin Hippmann \& Markus Linnemann. 2012. Sprachförderung in Deutschen Schulen - die Sicht der Lehrerinnen und Lehrer. Mercator Institut.

Ben Rafael, Eliezer. 1994. Language, Identity and Social Division. Oxford: Clarendon Press.

Berger, Einat. 2001. Absorption problems in a multicultural society: Selected issues of professional integration of immigrant teachers from the former Soviet Union into the education system in northern Israel. Unpublished $\mathrm{PhD}$ thesis. http://library.macam.ac.il/ study/pdf_files/d9137.pdf (accessed 26 July 2021).

Blommaert, Jan. 2010. The Sociolinguistics of Globalization. Cambridge: Cambridge University Press.

Bonnet, Andreas \& Peter Siemund (eds.). 2018. Foreign Language Education in Multilingual Classrooms. Amsterdam, Philadelphia: John Benjamins.

Bourdieu, Pierre. 1990. Was Heißt Sprechen? Die Ökonomie des Sprachlichen Tausches. Wien: Braumüller.

Bräu, Karin, Viola B. Georgi, Yasemin Karakaşoğlu-Aydın \& Carolin Rotter (eds.). 2013. Lehrerinnen und Lehrer mit Migrationshintergrund: Zur Relevanz eines Merkmals in Theorie, Empirie und Praxis. Münster, New York, München, Berlin: Waxmann.

BReg. 2015. Rede von Bundeskanzlerin Angela Merkel beim Deutschen Fürsorgetag am 17. Juni 2015. http://www.bundesregierung.de/Content/DE/Rede/2015/06/2015-06-18merkel-fuersorgetag.html (accessed 26 July 2021).

Brizić, Katharna. \& Claudia Hufnagl. 2016. Profile der Vielsprachigkeit und ihr Bildungserfolg. Der Deutschunterricht - Beiträge zu seiner Praxis und wissenschaftlichen Grundlegung, Themenheft: Mehrsprachigkeit (6). 21-32.

Bucholtz, Mary \& Kira Hall. 2005. Identity and interaction: A sociocultural linguistic approach. Discourse Studies 7 (4-5). 585-614.

BpB - Bundeszentrale für politische Bildung. 2019. Bevölkerung und Migrationshintergrund I: In absoluten Zahlen, Anteile an der Gesamtbevölkerung in Prozent, 2020. https://www.bpb.de/wissen/NY3SWU,0,0,Bev\%F6lkerung_mit_Migrationshintergrund_ I.html (accessed 26 July 2021)

Candelier, Michel \& Antoinette Camilleri-Grima et al. 2012. A Framework of Reference for Pluralistic Approaches to Languages and Cultures. Competences and Resources. Strasbourg: Council of Europe.

CNN Wire Staff. 2010. Education secretary says U.S. needs more minority teachers. http://edition.cnn.com/2010/POLITICS/08/28/duncan.minority.teachers/ (accessed 4 April 2017.)

Conteh, Jean \& Gabriela Meier (eds.). 2014. The Multilingual Turn in Languages Education: Opportunities and Challenges. Bristol: Multilingual Matters. 
Creese, Angela \& Adrian Blackledge. 2018. The Routledge Handbook of Language and Superdiversity. New York: Routledge.

Cummins, Jim. 2010. Language, Power, and Pedagogy: Bilingual Children in the Crossfire. Clevedon England, Buffalo N.Y.: Multilingual Matters.

Donmall, B. Gillian. 1985. Language Awareness. London: Centre for Information on Language Teaching and Research.

Duarte, Joana. 2016. Translanguaging in mainstream education: A sociocultural approach. International Journal of Bilingual Education and Bilingualism 22 (2). 1-15.

Fernández Amman, Eva M., Kropp Amina \& Johannes Müller-Lancé. 2015. Herkunftsbedingte mehrsprachigkeit im unterricht der romanischen Sprachen: Herausforderungen und chancen. In Eva M. Fernández Amman, Amina Kropp \& Johannes Müller-Lancé (eds.), Herkunftsbedingte Mehrsprachigkeit im Unterricht der Romanischen Sprachen, 9-22. Berlin: Frank \& Timme.

Franceschini, Rita. 2002. Sprachbiographien: Erzählungen über mehrsprachigkeit und deren erkenntnisinteresse für die spracherwerbsforschung und die neurobiologie der mehrsprachigkeit. Biografie linguistiche 76. 19-33.

Fürstenau, Sara \& Mechtild Gomolla. 2011. Migration und Schulischer Wandel: Mehrsprachigkeit. Wiesbaden: VS Verlag für Sozialwissenschaften.

Gantefort, Christoph \& María J. Sánchez Oroquieta. 2015. Translanguaging-strategien im sachunterricht der primarstufe: Förderung des leseverstehens auf basis der gesamtsprachigkeit. Transfer Forschung $\leftrightarrow$ Schule 1 (1). 24-37.

García, Ofelia \& Ricardo Otheguy. 2020. Plurilingualism and translanguaging: Commonalities and divergences. International Journal of Bilingual Education and Bilingualism 23 (1). $17-35$.

García, Ofelia \& Li Wei. 2014. Translanguaging: Language, Bilingualism and Education. Basingstoke, Hampshire, New York: Palgrave Macmillan.

Garrett, Peter. 2010. Attitudes to Language. Cambridge: Cambridge University Press.

Gawlitzek, Ira. 2013. Multilingualism, Literacy and Their Natural and Cultural Prerequisites. In J. F. Maas, S.-C. Ehmig \& C. Seelmann (eds.), Prepare for Life! Raising Awareness for Early Literacy Education, 116-120. Mainz: Stiftung Lesen.

Georgi, Viola B., Lisanne Ackermann \& Nurten Karaka. 2011. Vielfalt im Lehrerzimmer. Selbstverständnis und Schulische Integration von Lehrenden mit Migrationshintergrund in Deutschland. Münster: Waxmann Verlag GmbH.

Gkaintartzi, Anastasia, Angeliki Kiliari \& Roula Tsokalidou. 2015. 'Invisible' bilingualism 'invisible' language ideologies: Greek teachers' attitudes towards immigrant pupils' heritage languages. International Journal of Bilingual Education and Bilingualism 18 (1). $60-72$.

Goltsev, Evghenia, Galina Putjata \& Anastasia Knaus. 2021. Minority teachers - Potentials, challenges and implications. In Beckermann, Z. \& Zayusi, W. (eds.), Minority Teachers in Majoritarian Educational Settings. International perspectives, in press.

Guiora, Alexander, Benajamin Beit-Hallahmi, Robert Brannon, Cecelia Dull \& Thomas Scovel. 1972. The effects of experimentally induced changes in ego states on pronunciation ability in a second language: An exploratory study. Comprehensive Psychiatry 13 (5). 139-150.

Gürsoy, Erkan \& Heike Roll. 2018. 23. Schreiben und Mehrschriftlichkeit - zur funktionalen und koordinierten Förderung einer mehrsprachigen Literalität. In Wilhelm Grießhaber \& Sabine Schmölzer-Eibinger \& Heike Roll \& Karen Schramm (eds.), Schreiben in der Zweitsprache Deutsch, 350-364. Berlin, Boston: De Gruyter Mouton.

Hino, Nobuyuki. 2021. Language education from a post-native-speakerist perspective: The case of English as an international language. Russian Journal of Linguistics 25 (2). 528-545. https://doi.org/10.22363/2687-0088-2021-25-2-528-545 
Horowitz, Tamar. 2003. The increasing political power of immigrants from the former Soviet Union in Israel: From passive citizenship to active citizenship. International Migration 41 (1). 47-73.

$\mathrm{Hu}$, Adelheid. 2018. Plurilinguale Identitäten? Entwicklungen in der Theoriebildung und empirische Forschungsergebnisse zur Mehrsprachigkeit an Schulen. The Langscape Journal 1. 66-84.

Huxel, Katrin. 2018. Berufskultur und Lehrersein. Kulturtheoretische Zugänge in der Lehrerforschung. Zeitschrift Für Interpretative Schul- und Unterrichtsforschung 7 (1). 109-121.

Ingersoll, Richard \& Henry May. 2016. Minority Teacher Recruitment, Employment and Retention: 1987 to 2013. Learning Policy Institute.

Irvine, Judith T. \& Susan Gal. 2000. Language ideology and linguistic differentiation. In Paul V. Kroskrity (ed.), Regimes of Language: Ideologies, Polities, and Identities, 35-84. Santa Fe: School of American Research Press.

König, Katharina. 2018. Deutsch mit und ohne Akzent. Positionierung in Spracheinstellungsäußerungen unter dem Einfluss von Sprachideologien. In Kersten S. Roth, Karen Schramm \& Jürgen Spitzmüller (eds.), Phänomen, Mehrsprachigkeit': Einstellungen, Ideologien, Positionierungspraktiken, 89-106. Duisburg: Universitätsverlag Rhein-Ruhr.

Krashen, Stephen. 1987. Principles and Practice in Second Language Acquisition. Englewood Cliffs, N.J.: Prentice-Hall International.

Krüger-Potratz, Marianne. 2013. Vielfalt im lehrerzimmer. Aktuelle bildungspolitische entwicklungen unter der frage von kontinuitäten und diskontinuitäten. In Karin Bräu, Viola B. Georgi, Yasemin Karakaşoğlu-Aydın \& Carolin Rotter (eds.), Lehrerinnen und Lehrer mit Migrationshintergrund: Zur Relevanz eines Merkmals in Theorie, Empirie und Praxis, 17-36. Münster, New York, München, Berlin: Waxmann.

Lanza, Elisabeth. 2007. Multilingualism and the family. In Peter Auer \& Wei Li (eds.), Handbook of Multilingualism and Multilingual Communication, 45-67. Berlin: Mouton de Gruyter.

Lengyel, Drorit \& Lisa Rosen. 2015. Minority teachers in different educational contexts: Introduction. Tertium Comparationis. Journal ür International und Interkulturell Vergleichende Erziehungswissenschaft 21 (2). 153-160.

Levenberg, Ilana, Dorit Patkin \& Yael Sarfaty. 2013. New immigrant teachers social assimilation among school staff. International Academic Workshop on Social Science (IAW-SC 2013).

Mary, Latisha \& Andrea Young. 2018. Parents in the playground, headscarves in the school and an inspector taken hostage: Exercising agency and challenging dominant deficit discourses in a multilingual pre-school in France. Language, Culture and Curriculum 31 (3). 318-332.

May, Stephen. 2019. Negotiating the multilingual turn in SLA. The Modern Language Journal 103. $122-129$.

Mayring, Philipp. 2010. Qualitative Inhaltsanalyse. In Günter Mey \& Katja Mruck (eds.), Handbuch Qualitative Forschung in der Psychologie, 601-613. Wiesbaden: VS / Springer.

Meier, Gabriela S. 2017. The multilingual turn as a critical movement in education: Assumptions, challenges and a need for reflection. Applied Linguistics Review 8 (1). 100.

Melo-Pfeifer, Silvia \& Christian Helmchen. 2018. Plurilingual Literacy Practices at School and in Teacher Education. Berlin, Bern, Bruxelles, New York, Oxford, Warszawa, Wien: Peter Lang. 
Menken, Kate \& Ofelia Garcia (eds.). 2010. Negotiating Language Policies in Schools: Educators as Policymakers. New York: Routledge.

Muchnik, Malka, Marina Niznik, Anbessa Teferra \& Tania Gluzman. 2016. Elective Language Study and Policy in Israel: A Sociolinguistic and Educational Study. London \& New York: Palgrave Macmillan.

Oomen-Welke, Ingelore. 2013. Mehrsprachigkeit in der Klasse Wahrnehmen, Aufgreifen, Fördern. Stuttgart: Fillibach bei Klett.

Pajares, M. F. 1992. Teachers' beliefs and educational research: Cleaning up a messy construct. Review of Educational Research 62 (3). 307-332.

Panagiotopoulou, Argyro \& Lisa Rosen. 2016. Sprachen werden benutzt, „um sich auch gewissermaßen abzugrenzen von anderen Menschen“. In Thomas Geier \& Katrin U. Zaborowski (eds.), Migration: Auflösungen und Grenzziehungen: Perspektiven Einer Erziehungswissenschaftlichen Migrationsforschung, 169-190. Wiesbaden: Springer VS.

Pavlenko, Aneta. 2007a. Autobiographic narratives as data in applied linguistics. Applied Linguistics 28 (2). 163-188.

Pavlenko, Aneta. 2007b. Emotions and Multilingualism. Cambridge: Cambridge University Press.

Pavlenko, Aneta \& Adrian Blackledge. 2004. New theoretical approaches to the study of negotiation of identity in multilingual contexts. In Aneta Pavlenko \& Adrian Blackledge (eds.), Negotiation of Identities in Multilingual Contexts, 1-33. Clevedon: Multilingual Matters.

Prashizky, Anna \& Larissa Remennick. 2015. Cultural capital in migration: Fishka association of young Russian-speaking adults in Tel-Aviv, Israel. Journal of Intercultural Studies 36 (1). 17-34.

Prediger, Susanne \& Erkan Özdil (eds.). 2011. Mathematiklernen unter Bedingungen der Mehrsprachigkeit: Stand und Perspektiven der Forschung und Entwicklung in Deutschland. Münster: Waxmann.

Pulinx, Reinhilde \& Piet van Avermaet. 2015. Integration in Flanders (Belgium) - Citizenship as achievement: How intertwined are 'citizenship' and 'integration' in Flemish language policies? Journal of Language and Politics 14 (3). 335-358.

Putjata, Galina. 2014. Wenn Hände Eine neue Sprache Lernen: Gestikerwerb Bei Französisch, Spanisch- und Russischsprachigen Deutsch-L2-Lernern. Frankfurt am Main; New York: Peter Lang Edition.

Putjata, Galina. 2017a. "My teacher had an accent too": Immigrant teachers' and counselors' role in multicultural development-Perspectives of multilingual Israelis. Journal of Education 197 (3). 14-24.

Putjata, Galina. 2017b. "New language education policy" - Policy making and enhancement of migrant-related multilingualism in student's own perception. Zeitschrift für Erziehungswissenschaft 20 (2). 259-278.

Putjata, Galina. 2018a. Delivering multilingual schools - Emergence and development of language beliefs in immigrant teachers. Applied Linguistics Papers 25 (2). 53-69.

Putjata, Galina. 2018b. Der Wandel mehrsprachigkeitsbezogener Identitätskonstrukte im Kontext israelischer Migrationspolitik. In Kersten Sven Roth, Karen Schramm \& Jürgen Spitzmüller (eds.), OBST - Phänomen, Mehrsprachigkeit‘: Einstellungen, Ideologien, Positionierungspraktiken, 149-167. Duisburg: Universitätsverlag Rhein-Ruhr.

Putjata, Galina. 2018c. Immigrant teachers' integration and transformation of the linguistic market in Israel. Language and Education 21 (2). 1-17.

Remennick, Larissa. 2002. Survival of the fittest: Russian immigrant teachers speak about their professional adjustment in Israel. International Migration 40 (1). 99-121. 
Reusser, Kurt, Christine Pauli \& Anneliese Elmer. 2011. Berufsbezogene Überzeugungen von Lehrerinnen und Lehrern. In Ewald Terhart (ed.), Handbuch der Forschung zum Lehrerberuf, 478-496. Münster: Waxmann.

Roth, Kersten S., Karen Schramm \& Jürgen Spitzmüller (eds.). 2018. Phänomen ,Mehrsprachigkeit': Einstellungen, Ideologien, Positionierungspraktiken. Duisburg: Universitätsverlag Rhein-Ruhr.

Schmid, Monika. 2010. New perspectives on L1 attrition. Bilingualism: Language and Cognition 13 (1). 1-83.

Schumann, John. 1978. The Pidgination Process: A Model for Second Language Acquisition. Rowley, MA: Newbury House.

Shohamy, Elana. 2010. Cases of language policy resistance in Israel's centralized educational system. In Kate Menken \& Ofelia Garcia (eds.), Negotiating Language Policies in Schools: Educators as Policymakers, 182-197. New York: Routledge.

Shohamy, Elana. 2008. At what cost? Methods of language revival and protection: Examples from Hebrew. In King Kendall, Schilling-Estes Natalie, Fogle Lyn, Jia Lou \& Barbara Soukup (eds.), Sustaining Linguistic Diversity: Endangered and Minority Languages and Language Varieties, 205-2018. Washington DC: Georgetown University Press.

Spitzmüller, Jürgen \& Ingo H. O. Warnke. 2011. Diskurslinguistik: Eine Einführung in Theorien und Methoden der Transtextuellen Sprachanalyse. Berlin: De Gruyter.

Spolsky, Bernard. 2017. Language policy in education: Practices, ideology, and management. In Teresa L. McCarty \& Stephen May (eds.), Language Policy and Political Issues in Education, 3-16. Cham: Springer International Publishing.

Spolsky, Bernard \& Elana Shohamy. 1999. The Languages of Israel: Policy, Ideology and Practice. Clevedon: Multilingual Matters.

Yelenevskaya, Maria \& Ekaterina Protassova. 2021. Teaching languages in multicultural surroundings: New tendencies. Russian Journal of Linguistics 25 (2). 546-568. https://doi.org/10.22363/2687-0088-2021-25-2-546-568

\section{Article history:}

Received: 14 May 2021

Accepted: 19 October 2021

\section{Bionote:}

Galina PUTJATA is Professor for literacy and migration-related multilingualism at the Department of Education of the Goethe University Frankfurt (Germany). She obtained her $\mathrm{PhD}$ on multilingual development at University of Dresden and Université du Québec à Montréal. She further conducted research on multilingualism, migration and education at the universities of Münster, Landau and Flensburg. Her current research interests are: language and education trajectories in the context of transnationalisation, school development with a focus on language education and multilingualism, and professionalization in dealing with linguistic diversity.

\section{Contact information:}

Department for Educational Research

Goethe University Frankfurt

Theodor-W-Adorno-Platz 6

60629 Frankfurt, Germany

e-mail:putjata@em.uni-frankfurt.de

ORCID: 0000-0001-7745-3508 


\section{Сведения об авторе:}

Галина ПУТЯТА - профессор кафедры грамотности и многоязычия в условиях миграции во Франкфуртском университете имени Гёте (Германия). Она защитила докторскую диссертацию по многоязычному развитию в Дрезденском университете и Университете Квебека в Монреале. Впоследствии она исследовала вопросы многоязычия, миграции и образования в университетах Мюнстера, Ландау и Фленсбурга. В настоящее время ее научными интересами являются: языковые практики в условиях транснационализации, исследование многоязычия в области школьного и учебного развития, а также профессиональная подготовка в работе с языковым разнообразием.

\section{Контактная информация:}

Department for Educational Research

Goethe University Frankfurt

Theodor-W-Adorno-Platz 6

60629 Frankfurt, Germany

e-mail:putjata@em.uni-frankfurt.de

ORCID: 0000-0001-7745-3508 